Received: 23/10/2018

Revision: 02/02/2019

Accepted: $11 / 02 / 2019$

OnlineFirst:18/03/2019

\title{
The Impact of Using the Interactive E-Book on Students' Learning Outcomes
}

Asrowi

Dr., Universitas Sebelas Maret, Surakarta, Indonesia, asrowi@yahoo.com

Aufal Hadaya

Universitas Sebelas Maret, Surakarta, Indonesia,tp11040.aufalhadaya@gmail.com

Muhammad Hanif

Universitas Sebelas Maret, Surakarta, Indonesia, muhammadhanif@student.uns.ac.id

This study aimed to determine the impact of using the interactive e-book media on the students' learning outcomes in the historical topic of the social subject of the seventh class of junior high schools. This study employed the experimental research method involving 59 students in the control group and 59 students in the experimental group. The results showed that the mean score of the experimental group before using the e-book was 54.78 and the mean score after the treatment of using e-books was 81.69. This means that there has been an increase in the mean score by 26.91 after using the interactive e-book in the social subject. In addition, the results of the comparative test of the knowledge between the control and experimental groups showed that the experimental group had a mean score of 81.69 higher than the control group, which was 64.75 with the Sig. value of (2tailed) $0.000<0.05$ which means that there are significant differences in the scores between the control group and the experimental group. Hence, the interactive ebook media is effective to be used to improve the students' knowledge in the social subject of the seventh class.

Keywords: impact, e-book, interactive, learning outcomes, learning

\section{INTRODUCTION}

Books are one of the learning resources in teaching and learning activities both at the elementary and college level. The Indonesian government through the Ministry of Education and Culture has provided textbooks as a form of curriculum management at the level of primary and secondary education. The Republic of Indonesia Government Regulation Number 32 Year 2013 Article 1 paragraph 23 describes the Textbooks as the main learning source to achieve Basic Competence and Core Competence. Textbooks function to improve the effectiveness and efficiency of learning.

Citation: Asrowi, Hadaya, A., \& Hanif, M. (2019). The Impact of Using the Interactive E-Book on Students' Learning Outcomes. International Journal of Instruction, 12(2), 709-722. https://doi.org/10.29333/iji.2019.12245a 
They can be used as a systematic syllabus to determine the boundaries of a subject. With the available content supported by relevant assignments and exercises, textbooks can significantly reduce the teacher's time and effort in preparing the material. In addition, textbooks also allow students to learn at their own pace, providing a sense of autonomy and independence (Lau et al., 2018). Hamalik (2011) explains that the existence of books will make it easier for teachers to carry out their duties, help students learn lessons and provide security for parents. Even so, some textbooks have weaknesses, which are books are not compiled according to the student diversity; the material prepared is not in accordance with the circumstances of the times; moreover if the system of delivering the book is less attractive, it will certainly be boring for students to learn it.

A preliminary study was conducted by the researcher by distributing questionnaires to 64 junior high school students. The questionnaire was used to determine the students' responses regarding textbooks currently used as learning resources. The results showed that the textbooks used by students today have several weaknesses, namely: 1) textoriented; 2) the textbooks are too thick; 3) heavy; 4) lack of exercises to measure the understanding of the material; 5) easily damaged/torn.

Today's technological sophistication not only contributes to the industrial-economic field but is also used as a valuable tool for learning design and can contribute a lot to the way students learn and how teachers teach. Technology has also transformed printed books into electronic ones. With several advantages of e-books, they become learning tools that are taken into account in the digital era. Sackstein, Spark, \& Jenkins (2015) stated that tablets and e-books are suitable tools for reading and learning, and can, therefore, be used for academic work.

In Indonesia, e-books have also been used in the world of education. The Ministry of Education and Culture has published an electronic book called the Electronic School Book (BSE). BSE Procurement aims to increase the students' motivation and interest in reading and help to procure textbooks more quickly and easily. These books can be downloaded by the students on http://bse.kemdikbud.go.id/ for free since 2008 .

Books in the electronic version are considered capable of overcoming some limitations of the printed book. Compared to the conventional printed books, e-books are more durable as they will not be torn like printed books. E-books have a more practical size that can be used anytime and anywhere just by using a handheld device. For students, this practical size will reduce the burden of carrying heavy books (Embong, Noor, Hashim, Ali, \& Shaari, 2012). Rao (2003) noticed that e-books are very easy to get and are always available without wasting time searching for books in bookstores and libraries. In addition, e-books are more environmentally friendly. We don't need to cut down trees to make an e-book. E-books can increase the access to information quickly and easily in obtaining educational materials (Yaya, 2015). E-books can also help students understand learning materials (Noor, Embong, \& Ridhuan, 2012). In addition, the research by Daniel \& Woody (2013) stated that students at home spend more time reading materials in the electronic version than the printed version. This shows that ebooks can increase the students' interest and reading time. 
As the technology develops, e-books not only consist of texts and images that are only one-way, but they also develop into interactive media capable of integrating audio, video, animation and simulation. Kouis \& Konstantinou (2014) stated that electronic books from a simple version in PDF format integrated with audio, video, animation, simulation, began to be adopted in conventional classroom teaching, distance education, online-learning or e-learning. The use of e-books in learning can help teachers improve teaching methods in the classroom (Embong et al., 2012). Electronic media used in learning can function as effective teaching aids (Areerachakul, 2015).

Unfortunately, BSE issued by the government has not been able to become an interactive media because it only provides texts and images. This means that BSE is still static, and it is no different from the printed book that the students use (Irawan, Sari, Setiyoningrum, 2011). Although the use of BSE can overcome the limitations of printed books in terms of portability, this does not necessarily indicate the student satisfaction in using it (Astuti, Siswandari, Santoso, 2017; Hasbiyati \& Khusnah, 2017).

Therefore, we design an interactive e-book that contains texts, images, learning videos, and interactive exercises. Learning videos are included to make it easier for the students to understand abstract materials while the exercise is made interactively where the students can answer the questions and find out the scores obtained at the end of the ebook section. This study measures the impact of using the interactive e-book on the achievement of the students' knowledge in the social subject. The researcher hypothesizes that there will be a positive impact from using the interactive e-book on the social subject of the seventh class.

\section{METHOD}

\section{Material}

The interactive e-book developed is an electronic book on the 2013 Curriculum-based Social Sciences (IPS) subject that includes the basic competence of "Understanding the chronology, change and continuity in the life of the Indonesians on political, social, cultural, geographical and educational aspects from the preliterate period, HinduBuddhist period to the Islamic period".

The interactive e-book is a type of electronic book development that contains not only texts and images but also audio, video, and interactive exercises. The interactive e-book used for this study was created using Adobe Acrobat DC software in PDF format which was integrated with learning videos and interactive exercises. The e-book was designed for the students to be able to see videos and do cognitive tests to measure their material understanding. The e-book was validated by three experts on each content and media aspects. The content validation refers to the aspects of appropriate content, display, and language feasibility. The media issues refer to aspects of the ease of use, flexibility and multimedia principles.

The e-book design includes concept maps, competency pages, learning objectives pages, material accompanied by learning images and videos, summaries, exercises, and glossaries. In BSE, the students will only find ten multiple-choice questions in each 
chapter. The number is considered less to measure the students' knowledge of the learning material. Therefore, we designed more types of exercises to help them measure their cognitive abilities by providing three types of practice questions namely multiple choices, true-false quizzes, and fill-in-the-blank questions. At the end of the exercise will be displayed scores obtained by the students so that they can independently evaluate their cognitive abilities.

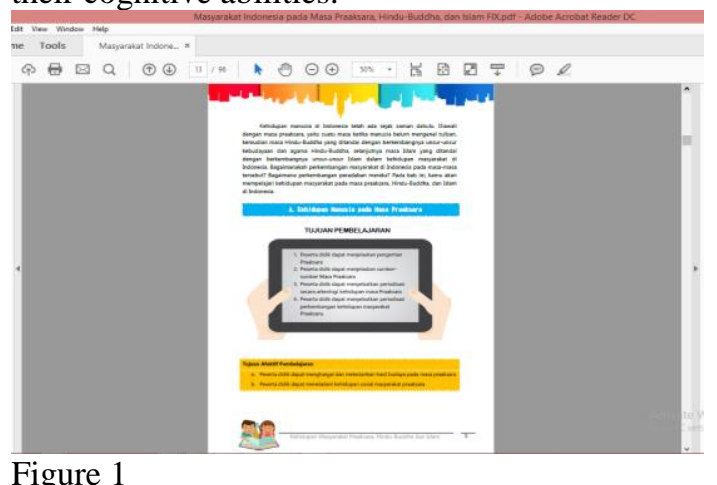

Figure 1

The Display of Learning Objectives

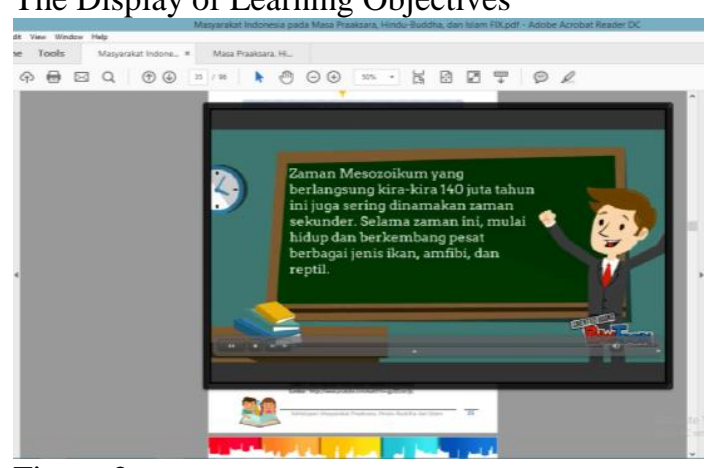

Figure 2

The Display of Learning Video

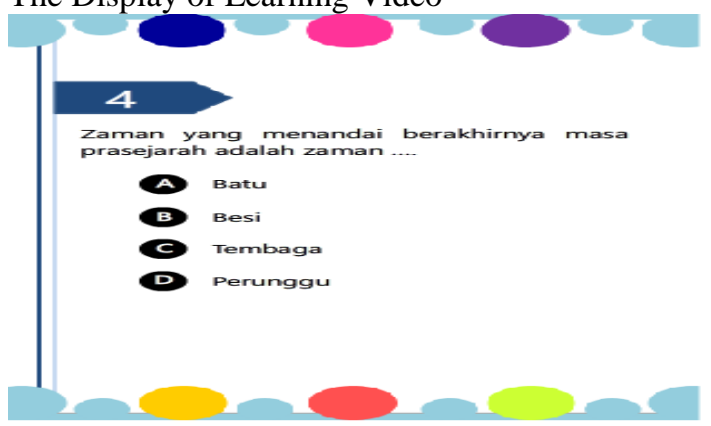

Figure 3

The Display of Multiple-Choice Questions 


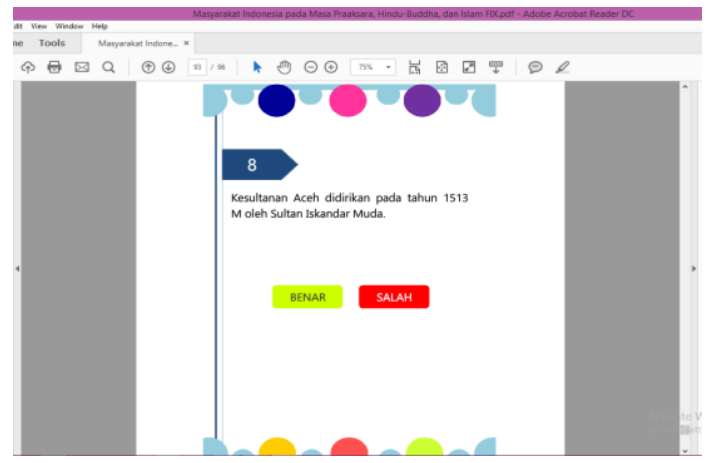

Figure 4

The Display of True-False Questions

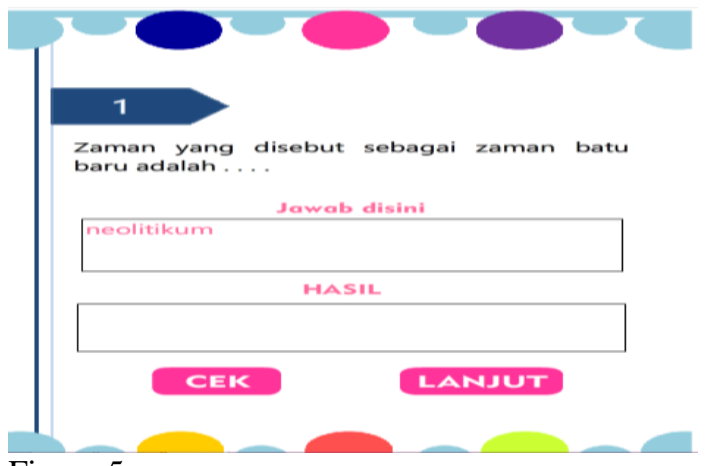

Figure 5

The Display of Fill-in-the-Blank Questions

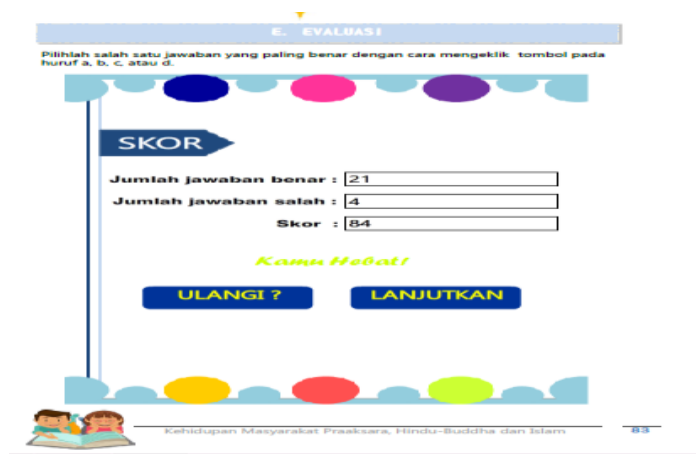

Figure 6

The Display of Scores Obtained by the Students

\section{Experimental Design}

The method used in this study was a quantitative experimental method with the Nonequivalent Control-Group design. In this design, there were two groups, namely the 
control group and the experimental group. The control group learned using printed textbooks while the experimental group learned using interactive e-books. Before starting the lesson, the two groups were given a pre-test to find out the initial conditions of whether both were equal.

\begin{tabular}{|c|c|c|}
\hline $\mathbf{O}_{1}$ & $\mathbf{x}$ & $\mathbf{O}_{2}$ \\
\hline $\mathbf{O}_{3}$ & & $\mathbf{O}_{4}$ \\
\hline
\end{tabular}

Figure 7

Experimental Design (Sugiyono, 2015)

$\mathrm{O}_{1}$ and $\mathrm{O}_{3}$ are the initial conditions of the students before the treatment. $\mathrm{O}_{2}$ is the students after using the interactive e-book product while $\mathrm{O}_{4}$ is the students who did not use the interactive e-book product (printed books). If the students' knowledge of the experimental class $\left(\mathrm{O}_{2}\right)$ differ significantly compared to those of the control group $\left(\mathrm{O}_{4}\right)$, the interactive e-book is more effective than the conventional printed book.

\section{Hypotheses}

The hypotheses used to make test decisions are as follows:

$\mathrm{H}_{0}$ : there are no differences in the post-test scores between the control group and the experimental group

$\mathrm{H}_{1}$ : there are differences in the post-test scores between the control group and the experimental group

The criterion used in making test decisions is $\alpha=0.05$ or $5 \%$. H0 is accepted if the significance value is $<0.05$ and it is rejected if the significance value is $>0.05$.

\section{Participant}

The samples in this study were 118 students from two junior high schools (Seventh Class) in Surakarta, Indonesia. Purposive sampling was applied in this study. In accordance with the purpose of this study, that researcher would like to see the impact of using the interactive e-book on the students' knowledge. Thus, the researcher chose the schools that have provided facilities in the form of computers/laptops for learning. The selected samples were the students who have been able to operate a laptop and have used BSE.

\section{Procedure}

The e-book that was created was implemented in the classroom learning. Learning was conducted for $4 \mathrm{x}$ meetings, each of which lasted for $2 \times 45$ minutes. Before learning, the students were given a pre-test to find out the initial abilities of the control and experimental groups. The post-test was carried out after the students completed learning the chapter. 


\section{Data Collection and Analysis}

The data were collected from the results of the knowledge test on the learning material in the chapter "Indonesian Communities in the Preliterate, Hindu-Buddhist and Islamic Period". The data were the pre-test data (before treatment) and post-test data (after treatment).

The pre-test data were used to test the comparison between students' initial knowledge in the control group and the experimental group. The post-test data were used to test the impact of using the interactive e-book on the students' knowledge by comparing the test scores of the control group and the experimental group. The data were tested using the independent sample t-test. Previously, it is necessary to perform the analysis prerequisite tests, namely the normality test, homogeneity test, and equality test. If the data analysis shows the experimental class knowledge differ significantly compared to the control group knowledge, the interactive e-book is more effective than conventional the printed book.

\section{FINDINGS}

\section{Data Description}

The impact of using the interactive e-book in the study was tested on scores of knowledge both pre-test and post-test scores. The pre-test data were used to carry out the equality test between the control group and the experimental group while the posttest data were used to carry out the independent samples t-test (the post-test score comparative test of control group and the experimental group). The following table presents the pre-test and post-test score data distribution

Table 1

Pre-test Data Distribution

\begin{tabular}{llll}
\hline \multirow{2}{*}{ Score } & $\mathrm{f}$ & & \multirow{2}{*}{$\mathrm{f}$} \\
\cline { 2 - 4 } & Control group & Experiment group & \\
\hline $36-44$ & 14 & 11 & 25 \\
\hline $45-53$ & 19 & 18 & 37 \\
\hline $54-62$ & 18 & 17 & 35 \\
\hline $63-71$ & 5 & 10 & 15 \\
\hline $72-80$ & 3 & 3 & 6 \\
\hline & 59 & 59 & 118 \\
\hline
\end{tabular}


Table 2

Post-test Data Distribution

\begin{tabular}{llll}
\hline \multirow{2}{*}{ Score } & $\mathrm{f}$ & & \multirow{2}{*}{$\mathrm{f}$} \\
\cline { 2 - 4 } & Control group & Experiment group & \\
\hline $41-50$ & 3 & - & 3 \\
\hline $51-60$ & 21 & - & 21 \\
\hline $61-70$ & 20 & 9 & 29 \\
\hline $71-80$ & 14 & 20 & 34 \\
\hline $81-90$ & 1 & 18 & 19 \\
\hline $91-100$ & - & 12 & 12 \\
\hline Total & 59 & 59 & 118 \\
\hline
\end{tabular}

Before conducting the comparative test of the learning outcomes, it is necessary to conduct the prerequisite tests including normality test, homogeneity test, and equality test.

\section{Normality test}

The normality test is used to assess whether the data distribution in a group of data analyzed is normal. To test the data normality, Kolmogorov-Smirnov Test was used in the SPSS 22 program. The data are said to be normally distributed if the significance value is $>0.05$. The results of the normality test of the experimental and control class learning outcome test results can be seen in Table 3.

Table 3

Tests of Normality

\begin{tabular}{lllll}
\hline \multirow{2}{*}{ Pretest } & Group & \multicolumn{4}{l}{ Kolmogorov-smirnov $^{\mathrm{a}}$} \\
\cline { 2 - 5 } & Statistic & $\mathrm{df}$ & Sig. \\
\cline { 2 - 5 } & Control & .110 & 59 & .071 \\
\hline Posttest & Experiment & .106 & 59 & .094 \\
& Control & .112 & 59 & .064 \\
& Experiment & .098 & 59 & $.200^{*}$ \\
\hline
\end{tabular}

Based on Table 3, the calculation of the normality test shows the Sig. value of the control-group pre-test is $0.071>0.05$ and the Sig. value of the experimental-class pretest is $0.094>0.05$. Then, the Sig. value of the control-group post-test is 0.064 and 0.200 for the Sig. value of the experimental-group post-test. Thus, it can be concluded that the data on the pre-test and post-test scores of both the control group and the experimental group are normally distributed.

\section{Homogeneity test}

The homogeneity test aims to determine whether the experimental and control groups have the same variance. The data are said to be homogeneous if the significance value is $>0.05$. 
Table 4

Test of Homogeneity of vVriances

\begin{tabular}{lllll}
\hline & Levene statistic & df1 & df2 & Sig. \\
\hline Pre-test & .141 & 1 & 116 & .708 \\
\hline Post-test & 1.282 & 1 & 116 & .260 \\
\hline
\end{tabular}

Based on Table 4, the Sig. value of the pre-test test data is 0.708 and the Sig. value of the post-test data is 0.260 . Both numbers show $>0.05$. It can be concluded that the scores of the learning outcome test of the control group and the experimental group have homogeneous variance.

\section{Equality test results}

The equality test was conducted to find out whether there were differences in the average initial ability of the students between the control group and the experimental group. The hypotheses used to make test decisions are as follows:

H0: there are no differences in the students' initial abilities between the experimental group and the control group

H1: there are differences in the students' initial abilities between the experimental group and the control group.

The two-sided test was performed with a significance level of $\alpha=0.05$ or $5 \%$ with a test decision that if the probability or significance/Sig. value is $>0.05$ then $\mathrm{H} 0$ is accepted and if the probability or significance/Sig. value is $<0.05$ then $\mathrm{H} 0$ is rejected.

Table 5

Mean of Pre-test Scores

\begin{tabular}{lllll}
\hline Group & $\mathrm{N}$ & Mean & Std. Deviation & Std. Error mean \\
\hline Control & 59 & 52.88 & 9.008 & 1.173 \\
\hline Experiment & 59 & 54.78 & 9.520 & 1.239 \\
\hline
\end{tabular}

Based on Table 5, the mean score of the pre-test from the control group is 52.88 while the mean score of the experimental group is 54.78. Table 6 shows the Independent Samples T-Test data on $F$ test is 0.141 with a probability of $0.708>0.05$ and $t$ of -1.113 $>-1.658$ (the value of $t$-table $\mathrm{df}=116$ ) with Sig. (2-tailed) of 0.268 . The Sig. value (2tailed) showed that the score is greater than 0.05 so that $\mathrm{H} 0$ is accepted and $\mathrm{H} 1$ is rejected. This means there are no significant differences between the average initial ability of the students in the control group and the experimental group before the treatment of the interactive e-book. Thus, the two groups are considered equal and are eligible for the comparative test. 
Table 6

Equality Test Results (Independent Samples T-Test)

\begin{tabular}{llrrr}
\hline & & \multicolumn{2}{c}{ Score } \\
\cline { 3 - 4 } & & $\begin{array}{r}\text { Equal variances } \\
\text { assumed }\end{array}$ & $\begin{array}{r}\text { Equal variances } \\
\text { not assumed }\end{array}$ \\
\hline \begin{tabular}{l} 
Levene's Test for $\begin{array}{l}\text { Equality of } \\
\text { Variances }\end{array}$ \\
\cline { 2 - 4 } $\begin{array}{l}\text { t-test for Equality } \\
\text { of Means }\end{array}$
\end{tabular} & $\mathrm{F}$ & .141 & \\
\cline { 2 - 5 } & Sig. & .708 & -1.113 \\
\cline { 2 - 5 } & $\mathrm{d}$ & -1.113 & .268 \\
\cline { 2 - 5 } & Sig. (2-tailed) & 116 & -1.898 \\
\cline { 2 - 5 } & Mean Difference & -268 & 1.706 \\
\cline { 2 - 5 } & Std. Error Difference & 1.898 & -5.278 \\
\cline { 2 - 5 } & $\begin{array}{l}\text { 95\% Confidence Interval } \\
\text { of the Difference }\end{array}$ & Lower & -5.278 & 1.481 \\
\cline { 2 - 5 } & & Upper & 1.481 & \\
\hline
\end{tabular}

\section{The impact of the interactive e-book on the students' learning outcomes}

The impact of using the interactive e-book in this study was measured by comparing the post-test scores between the control group and the experimental group. The results are shown in Tables 7 and 8.

Table 7

Mean of Post-test Score

\begin{tabular}{lllll}
\hline Group & $\mathrm{N}$ & Mean & Std. Deviation & Std. Error mean \\
\hline Control & 59 & 64.75 & 8.804 & 1.146 \\
\hline Experiment & 59 & 81.69 & 10.190 & 1.327 \\
\hline
\end{tabular}

Based on Table 7, the mean post-test score in the control group is 64.75 and in the experimental group is 81.69. Descriptively, the test results show a difference in the scores between the control and experimental groups of 16.94. Thus, the mean score of the experimental group is higher than that of the control group.

Table 8

Media Effectiveness Test Results (Independent samples T-test)

\begin{tabular}{|c|c|c|c|}
\hline & & \multicolumn{2}{|l|}{ Score } \\
\hline & & $\begin{array}{l}\text { Equal variances } \\
\text { assumed }\end{array}$ & $\begin{array}{l}\text { Equal variances } \\
\text { not assumed }\end{array}$ \\
\hline \multirow{2}{*}{$\begin{array}{l}\text { Levene's test for } \\
\text { equality of } \\
\text { variances }\end{array}$} & $\mathrm{F}$ & 1.282 & \\
\hline & Sig. & .260 & \\
\hline \multirow{7}{*}{$\begin{array}{l}\text { T-test for equality } \\
\text { of means }\end{array}$} & $\mathrm{t}$ & -9.668 & -9.668 \\
\hline & $\overline{\mathrm{df}}$ & 116 & 113.604 \\
\hline & Sig. (2-tailed) & .000 & .000 \\
\hline & Mean difference & -16.949 & -16.949 \\
\hline & Std. Error difference & 1.753 & 1.753 \\
\hline & $95 \%$ Confidence Interval Lower & -20.421 & -20.422 \\
\hline & of the Difference & -13.477 & -13.476 \\
\hline
\end{tabular}


Based on Table 8 , the results of the comparative test using the independent sample t-test showed the $t$ value of $-9,668$ is < the t-table value $(-1,658)$ with Sig. value of $(2$ tailed) $0.000<0.05$. Thus, $\mathrm{H} 0$ is rejected and $\mathrm{H} 1$ is accepted which means that there is a significant difference in the scores between the control group and the experimental group so that the interactive e-book media is effective to improve the students' learning outcomes in the social subject of the seventh class of junior high schools.

\section{DISCUSSION}

The interactive e-book was designed based on the learning needs of the junior high school students on the social subject. Unlike BSE, this interactive e-book provides several animated learning videos and interactive exercises. The existence of learning videos is intended to make the students easier to understand abstract materials. As revealed by Hidayati \& Wuryandari (2012), animation media can make students understand the topics presented more easily. The additional e-book as the independent reading resource for the students provides a new reading experience for them. Especially if enriched with multimedia (animation, music, sound, spotlight), e-books can attract, motivate, gather the students' attention and perseverance in reading (Roskos, Brueck, \& Lenhart, 2017). Roslina, et al. (2013) stated that the use of e-books made learning more interesting and fun and doing homework easier.

The interactive exercise is one of the features provided in the e-book. This feature aims to train the depth of the students' knowledge of the material that has been studied. They can answer the questions that have been provided and find out the score they have obtained.

The experimental results showed that the students who used the interactive e-book obtained superior learning outcomes than those who used textbooks. Zhang \& Deng (2004) note that students are easier to pay attention to and the lesson becomes more interesting when the teacher uses a variety of multimedia teaching tools rather than just textbooks. Using multimedia is effective to teach the lesson (Aloraini, 2012).

These results are in line with the research of Hsiao, Tiao, \& Chen (2016) which states that learning outcomes are far better achieved by the participants in the interactive ebook group than those who use Powerpoint. The results are also supported by the research from Candra \& Irianto (2016) in their study showing that the students' learning outcomes by applying the contextual learning model using e-books are better than those by applying the contextual learning model using handouts.

The research conducted by Prihantana, Santyasa \& Warpala (2014) also stated that the use of interactive teaching materials can significantly improve the students' learning outcomes. Hasbiyati \& Khusnah (2017) also revealed that the E-Book implementation with the epub extension can increase the learning interest very well by $88.61 \%$ and can improve the students' learning outcomes with the high criterion in the form of a gain score of 0.703 in the junior high school science learning.

Astuti, Siswandari, Santoso (2017) stated that using e-book media based on Problem Based Learning can improve the material understanding and mastery of competencies in 
the learning process so as to improve the students' learning outcomes to the full. Multimedia-based teaching materials can effectively improve the students' learning achievement (Yang, Tseng, Liao, \& Liang, 2013).

Besides being able to improve the students' learning outcomes, the use of this interactive e-book also encourages the teachers to have creativity in providing learning materials suitable for their students' needs. Richards \& Renandya (2002) explained that the use of a determined textbook would tend to limit the teacher's creativity in designing the learning material. The teacher will only deliver the material as recommended without taking the initiative to adjust the material to meet the needs of diverse students (Lau, Lam, Kam, Nkhoma, Richardson, \& Thomas, 2018). Textbooks that are designed based on the students' needs will provide satisfaction for the students. As revealed by Joo, Park, \& Shin (2017), the perception of usability in digital textbooks increases because expectations are fulfilled.

In addition to encouraging teachers to be more creative in providing learning materials, the use of this interactive e-book fits the characteristics of today's students. They are said to be the digital natives/ digital generation where they have a high interest in adopting technology. This is a great potential to increase the effectiveness of classroom learning using technology. By using technology, learning will become more interesting and fun for the students. Zhang \& Deng (2004) in his study found that the students were easier to pay attention to and the lesson became more interesting when the instructors used various multimedia teaching tools rather than relying solely on textbooks

\section{CONCLUSION}

A textbook is an important element in learning. The government has provided textbooks as a form of curriculum management to support the effectiveness and efficiency of learning. Even though the teacher and students get convenience with the textbook, it does not mean the textbook does not have weaknesses. The proposed e-book is proofed can enhance the students learning outcomes in form of knowledge.

Interactive e-books can be an alternative solution to the limitations of the textbook (printed). This is evidenced in the group using the interactive e-book which had better learning outcomes compared to that using the printed textbook. Although the development of this interactive e-book has a positive impact, it should be remembered that to develop interactive teaching materials must be based on the student learning needs. This needs to be done so that the students can massively benefit from the use of the e-book.

\section{LIMITATION}

This study only measures the impact of interactive e-book in knowledge aspect, while another aspect of learning outcomes such as skill, attitude and other standard achievements can be potential to be studied. The developed e-book is designed specifically in a limit sub competence so that, for further research, user satisfaction and other potential and challenges in the effectiveness of interactive e-book still can be deeply studied in other context and setting of participant. 


\section{REFERENCES}

Aloraini, S. (2012). The impact of using multimedia on students' academic achievement in the College of Education at King Saud University. Journal of King Saud University Languages and Translation, 24, 75-82.

Areerachakul, S. (2015). Using Electronic Medias for Science Mathematics and English in School under Office of the Basic Education Commission, Thailand. Procedia - Social and Behavioral Sciences, 197, 1558 - 1563.

Astuti, D. P., Siswandari, \& Santoso, D. (2017). E-Book for Problem Based Learning to Improve Learning Outcome of the Students. Proceeding: Advances in Social Science, Education and Humanities Research, 158, 220-227.

Candra, D. N., \& Irianto, D. (2016). Perbandingan Hasil Belajar Siswa Antara Pembelajaran Contextual Teaching Learning (CTL) Menggunakan E-Book dan Pembelajaran Konvensional Menggunakan Handout Pada Mata Pelajaran Kontruksi Bangunan di Kelas X TGB SMK Negeri 2 Bojonegoro. Jurnal Kajian Pendidikan Teknik Bangunan, 1(1), 189-194.

Embong, A. M., Noor, A. M., Hashim, H. M., Ali, R. M., \& Shaari, Z. H. (2012). EBooks as textbooks in the classroom. Procedia - Social and Behavioral Sciences, 47, 1802-1809.

Daniel, D. B., \& Woody, W. D. (2013). E-textbooks at what cost? Performance and use of electronic v. print texts. Computers and Education, 62, 18-23.

Hamalik, O. (2011). Dasar-dasar Pengembangan Kurikulum (Basic Curriculum Development). Bandung: PT. Remaja Rosadakarya.

Hasbiyati, H., \& Khusnah, L. (2017). Penerapan Media E-Book Berekstensi Epub untuk Meningkatkan Minat dan Hasil Belajar Siswa SMP Pada Mata Pelajaran IPA. Jurnal Pena Sains, 4(1), 16-21.

Hidayatai, N., \& Wuryandari, A. I. (2012). Media Design for Learning Indonesian in Junior High School Level. Procedia - Social and Behavioral Sciences, 67, 490 - 499.

Hsiao, C. C., Tiao, M. M., \& Chen, C. C. (2016). Using Interactive Multimedia EBooks for Learning Blood Cell Morphology in Paediatric Hematology. BMC Medical Education, 16, 290, 2-8.

Irawan, Z., Sari, M. E., Setyoningrum, M. U. (2011). Analisis Implementasi Kebijakan Buku Sekolah Elektronik (BSE) Kementerian Pendidikan Nasional di Sekolah Menengah Atas kota Yogyakarta. Pelita-Jurnal Penelitian Mahasiswa UNY, 6(1), 1-13.

Joo, Y. J., Park, S., \& Shin, E. K. (2017). Students' expectation, satisfaction, and continuance intention to use. Computers in Human Behavior, 69, 83-90.

Kouis, D., \& Konstantinou, N. (2014). Electronic textbooks advantages and challenges for the Hellenic higher education and publishing community. Library Review, 63(6/7), 531-543. 
Lau, K. H., Lam, T., Kam. B. H., Nkhoma, M., Richardson, J., Thomas, S. (2018). The role of textbook learning resources in e-learning: A taxonomic study. Computers \& Education, 118, 10-24.

Noor, A. M., Embong, A. M., \& Ridhuan, M. R. T. L. A. (2012). E-Books in Malaysian Primary Schools : The Terengganu Chapter. Ieee, 6(6), 298-301.

Government of the Republic of Indonesia. (2013). Government Regulation 32 Year 2013 about the Changes on the Government Regulation Number 19 Year 2005 about National Education Standard. Jakarta: Government of the Republic of Indonesia.

Prihantana, M. A. S., Santyasa, I. W., \& Warpala, I. W. S. (2014). Pengembangan Bahan Ajar Interaktif Berbasis Pendidikan Karakter Pada Mata Pelajaran Animasi Stop Motion untuk Siswa SMK. E-Journal of Postgraduate School of Universitas Pendidikan Ganesha Educational Technology Department, 4, 1-12.

Rao, S. S. (2003). Electronic books: a review and evaluation. Library Hi Tech, 21(1), 85-93.

Richards, J. C., \& Renandya, W. A. (2002). Methodology in Language Teaching: An anthology of current practice. Cambridge: Cambridge University Press.

Roskos, K., Brueck, J., Lenhart, L. (2017). An analysis of e-book learning platforms: Affordances, architecture, functionality and analytics. International Journal of ChildComputer Interaction, 12, 37-45.

Roslina, N., Fahmy, S., Fariha, Z., Haslinda, N., Yacob, A., Sukinah, N., Suhana, N. (2013). The Effect of e-Book on Students' Learning Styles A Study in Terengganu, Malaysia. Proceeding: Advances in Social Science, Education and Humanities Research, 228-231.

Sugiyono. (2015). Metode Penelitian Pendidikan Pendekatan Kuantitatif Kualitatif dan $R n D$. Bandung: Alfabeta.

Sackstein, S., Spark, L., \& Jenkins, A. (2015). Are e-books effective tools for learning? Reading speed and comprehension: iPad® vs. Paper. South African Journal of Education, 35(4), 1-14.

Yaya, J. A. (2015). Prospects and Challenges of E-Books in School Media Services in Nigeria: The Way Forward About E-Books. International Journal of Education and Information Technology, 1(3), 92-98.

Yang, C. C., Tseng, S. S., Liao, A. Y. H., \& Liang, T. (2013). Situated poetry learning using multimedia resource sharing approach. Educational Technology and Society, 16(2), 282-295.

Zhang, S. \& Deng, H. (2004). Perception of learning effectiveness in the multimedia classroom vs. the traditional classroom: A case study. Media Review, 11, 87-107. 